\title{
ПАВЛЕ ПОПОВИЋ И ЈЕЛЕНА ДИМИТРИЈЕВИЋ: КОНЦЕПЦИЈА ЦЕЛИНЕ ЈЕЛЕНИНИХ ПРИЧА О НИШУ
}

\begin{abstract}
Приповедни циклус о старом Нишу Јелена Димитријевић је започела стихованом „причом” Баба Краса, у мој земан и с’га, коју је објавила у часопису „Видело” 1892. године. У том гласилу је Павле Поповић тада био сарадник - новинар, али и уредник књижевног додатка. Књижевна сарадња П. Поповића са Ј. Димитријевић се индиректно наставила до 1903. године, када је књижевница објавила две приче о нишкој средини (1903. и 1905) у СКГ, у коме је Павле Поповић (са Скерлићем) био сарадник, а и уредник. Са последњом причом из овог циклуса, Мејрем ханум (1907), Јелена Димитријевић је заокружила књижевну целину социолошког пресека о старој вароши, са истакнутим карактерним особинама личности, као делом националног идентитета на прелазу векова. У раду ћемо се бавити концепцијом идејне приповедне целине из нишког миљеа. Већ поменутим и осталим познатим насловима из овог приповедног корпуса третираног у књижевној критици, додајемо два приповедна дискурса: Николаћ Малебашија (1903) и Батка Бунча и Стринка Мариче (1905), који се битно разликују од Јелениног дотадашњег наративног манира.

Кључне речи: Павле Поповић, Јелена Димитријевић, Српски књижевни гласник, приповетке, Ниш.
\end{abstract}

Наша тема: „Павле Поповић и Јелена Димитријевић: концепција целине Јелениних прича о Нишу" везује се за рани период Поповићевог литерарног ангажовања, односно, узели смо овде само период од 1892. до 1907. године. То је временски интервал када Јелена, поред песама, штампа и своја прозна дела - приповетке из нишког миљеа. На почетку тог периода, Павле Поповић је, као гимназијски професор у Београду, био и сарадник у часопису „Видело”. По речима академика Пантића, ту где је он „био више него сарадник, скоро уредник књижевне стране, штампане су, уз његово учешће поједине песме Јелене Димитријевић, што у разним рубрикама, што у 'књижевним додацима’ тога листа...”. Те, 1892. године, у свечаном, божићном броју „Ви-

\footnotetext{
${ }^{1}$ Мирослав Пантић, „Јелена Димитријевић и Павле Поповић”, у: Јелена Димитријевић, живот и дело, стр. 16.
} 
дела" објављена је Јеленина прича у стиху Баба Краса, у мој земан и с’га, са ауторкином жанровском одредницом „приповетка”. С пролећа 1894. почео је да излази дневни лист „Ред”, који је живео „до 9. маја исте године, а идуће 1895. појавио се Недићев 'Српски преглед', чисто књижевни (и такође борбен) часопис"; а ,jа сам са својим друштвом био сарадник у та два последња листа" писао је П. Поповић у Сећағима на Љубомира Стојановића ${ }^{2}$. И што је од посебног значаја за књижевни однос између Павла Поповића и Јелене Димитријевић у том раном периоду њеног литерарног стваралаштва јесте, свакако, Поповићева критичка оцена њене збирке Песме I (Ниш) из 1894, објављене у „Српском прегледу” 1895. године, у броју 7. Тиме је, како каже академик Пантић, Павле Поповић пружио „руку подршке 'тој дами' у српској књижевности”. Приказ ових песама Поповић је започео високом компаративном похвалом њеној књижевној личности, која гласи: „После Милице Српкиње, Јелена је колико знамо, прва Српкиња која пише песме... Њихова количина и каквоћа допушта им улазак у књижевност..." етску инспирацију са сензибилитетом источњачке лирике, он додаје да те песме са „заједничким тоном и предметом” чине циклус што носи одлике романа. Три деценије касније, својом изјавом у честитки за Јеленин јубилеј (1928) Павле Поповић је само потврдио свој позитиван став према њеном ранијем приповедном стваралаштву: „Доцније сам пратио са истим интересовањем Ваше приповетке и романе, као и путописе и налазио све већу вредност у Вашим даљим радовима...”" Тај радни однос и такав став је био већ раније потврђен штампањем Јелениних прича у СКГ 1903. и 1905. године, када је тамо Павле Поповић био (са Скерлићем) сарадник и уредник. Поред ових, у СКГ су штампани и следећи њени радови: Сафи ханум (1901), Писма из Солуна (1908. и 1909) и У Америци нешто се догодило (1924).

По годинама издања, њен приповедни корпус из нишког миљеа иде следећим редом:

Баба Краса, у мој земан и с'га, „Видело”, 1892.

Писма из Ниша о харемима, Београд, $1897 .^{5}$

Свети Пантелеј, „Бранково коло”, 1898.

Српска девојка, „Бранково коло”, 1900.

Ђул Марикина прикажња, 1901.

Николаћ Малебашија, „Српски књижевни гласник”, 1903.

Батка Бунча и Стринка Мариче, „Српски књижевни гласник”, 1905.

Мејрем ханум, приповетка из збирке од три приче (Фати султан, Сафи ханум, Мејрем ханум), Београд, 1907.

\footnotetext{
${ }^{2}$ Павле Поповић, Сабрана дела, къ. Х, стр. 112

${ }^{3}$ Павле Поповић, Песме Јелене Јов. Димитријевића, Сабрана дела, књига X, стр. 216

${ }^{4}$ Часопис Мисао XXIX, 1, 2, 1929, стр. 124

${ }_{5}^{5}$ Сагледавањем корпуса приповедака о старом Нишу, ова романескна проза се по форми и жанру не уклапа у композицију са осталим наративним целинама. Стога се овде осврћемо само на познату констатацију да је ово дело у тематско-композиционом погледу вишезначно. Централни део ове прозе, у жанру етнографских слика о богатој свадби у кући Бећир-бегових у Нишу представља литерарни сегмент о егзистенцији одлазећих турских породица из Србије. Тај фрагмент, издвојено посматран, чини се као део књижевно уобличеног записа о историјском тренутку, сада на југу земље, што ауторка потврђује XVI писмом. Уосталом, познато је да је пре изласка књиге „о харемима” из штампе 1897. године, краљ Александар Обреновић 1896. године за заслуге одликовао Јелену Димитријевић Орденом Светога Саве.
} 
Посматрано тематски, њена наведена дела која су објављена до 1903. године обрађују психосоциолошку проблематику из родног (женског) аспекта у нишкој вароши тек ослобођеној од Османлија.

\section{Баба Краса, у мој земан и с’га}

Прво дело из приповедног корпуса о Нишу, приповетка у стиху са пуним насловом Баба Краса, у мој земан и с’га (Баба Краса прича својој комшиници) објављено је 1892. године, али, по писму пријатељици Делфи Иванић, оно је доста раније „створено”. Јелена о томе, између осталог, износи следеће: „Како се Баба Краса крила иза капиџика, она права Баба Краса, тако је и ова из приповетке проводила своје дане сакривена у пишчевој фијоци. Имајте на уму, драга Госпођо и пријатељице, да је писац старе Баба Красе била тако млада женица, ма да је била удата већ скоро четири године. Београд, 26. августа, 1932."

Баба Красина песничка исповест односи се на време њене младости и старе патријархалне етике, која стоји у опозицији садашњем (њеном) добу. Као времешна жена, сада, на првој општинској забави - „балу” у граду, она доживљава слободно и отворено понашање младих, за њене појмове, као нешто недопустиво.

\section{„И врз очи тури руку} да не гледам грдну бруку.”’

Стихована нарација (стих у осмерцу кроз четири песничке целине) обликована кроз праволинијско излагање са опозиционим елементима: унутраспоља, пре-сада, пружа, поред дескрипције, и психолошко стање наратора. По тумачењу Богуслава Зјелињског, овакав реалистички књижевни поступак у XIX веку припада „балканском моделу” у методологији стварања. Баба Красиним исповедним ламентом и компарацијом сада и пре, књижевница Димитријевић третира однос, уопште према жени у трансформацији, где је лични живот ове јунакиње укомпоновала у нове токове средине.

Павле Поповић, у приказивању њене збирке песама из 1894. године, осврће се на ову стиховану причу и даје свој коментар у коме, између осталог, стоји: „Право да кажемо, дијалекат којим је Баба Краса писана, нама не изгледа нимало поетичан али, онакав какав је у овој песми, он показује нарочито вештину Јеленину и за овај род поезије. И после, у песми има доста лепих места, оригиналних компарација и пријатних слика наивности старог времена." Популарност овог Јелениног дела је била велика; уосталом, три пута је дело објављивано; за њен јубилеј, 1928. делегат из Ниша јој је поклонио

\footnotetext{
${ }^{6}$ Јелена Димитријевић, Писмо Госпођи Делфи Иванић, у: Календар Кола српских сестара за 1933, Београд, 1932.

${ }^{7}$ Јелена Димитријевић, Баба Краса, у мој земан и с'га, Песме I, део VI, Ниш, 1894, стр. 133

${ }^{8}$ Павле Поповић, Сабрана дела, књига X, стр. 219
} 
корпу цвећа, у „коме је и цветак баба-Красе, коју сте ви тако лепо описали”, како пише у тадашњој „Политици”.

\section{Српска девојка}

У „Бранковом колу” 1900. године Јелена Димитријевић објављује причу Српска девојка, која није имала публицитет попут Баба Красе, разумљиво, ни као Писма из Ниша, а ни као, касније, Бул Марикина прикажња. Па ипак, ова нарација има своје значајно место и улогу у корпусу Јелениних нишких прича. Њен значај је, пре свега, у поетици стварања, односно, у поетској трансформацији жанрова: као паралелизам, прича Српска девојка - народна лирска песма Српска дјевојка ${ }^{10}$. Ова песма је послужила списатељици као основ у приповедању за инспиративно моделирање карактерних особина главне личности, девојке Милене у хронотопу нових времена и простора. Она је лепа, паметна, вредна, тиха, али несрећна у традиционалним породичним околностима сеоске задруге.

Методолошки посматрано, почетак овог наративног дискурса у сликовитој сценској ситуацији прераста у нарацију, а затим, наратив уступа место наративности кроз дијалог и конверзацију. Са смењивањем жанрова (унутар дела) из прозе у поезију и обрнуто, и са читавом скалом стилских фигура: епитет, компарација, метафора итд., књижевница је начинила фолклорну српску повест, која би, по методама тумачења Дејвида Хермана и Вернера Вулфа у начину грађења, припала посткласичној наратологији.

\section{Ђул Марикина прикажња}

И следећа приповетка има женски главни лик, који, у исповедном облику, даје широк преглед узајамности: личног према породици и обрнуто. То је дуга приповест - новела Ђул Марикина прикажња, коју је Јелена објавила најпре у „Новој искри”, а затим целовито штампала 1901. у Државној штампарији Краљевине Србије. Као инспирација за „прикажњу” - бруку, књижевници је послужио немили догађај око удаје девојке из богате нишке чорбаџијске куће, чији је извор и заплет у одступању од уобичајеног понашања пре свадбе. У времену поштовања устаљених обичаја, сваки искорак доноси несрећу, па и трагедију: Марики је на дан свадбе отказана удаја, а жртва је и њен несуђени муж, који се, од туге за њом, разболео и умро. О овом приповедном дискурсу, са нарочито наглашеним догађањима: свадбе, славе, посела итд. критика је позитивно коментарисала („Градина”, СКГ), али пре свих „Бранково коло”, у најави нове књиге. Ту, између осталог, стоји: „ [...] Госпођина опсервација је јака, причање глатко, и слатко, она с љубављу

\footnotetext{
${ }^{9}$ Политика, бр. 7426, 31. децембар, 1928, стр. 8

${ }^{10}$ Вук Стефановић Караџић, Српске народне пјесме, стр. 599
} 
прати сваку мисао и покрет својих чељади. Како је дивно описан живот Срба Нишлија пре ослобођења, и то живот најинтимнији, живот кућевни породични у овој Ђул Марикиној прикажњи [...] а цела је приповетка писана скроз оним нишким дијалектом.”11 Међутим, „Коло”" нило Живаљевић је дао негативан осврт на ову причу. Тада се ауторка Димитријевић огласила преко штампе негирајући неке Живаљевићеве тврдње. Иза овога је уследио одговор уредника „Кола”, чиме је ток изјава добио полемички карактер, и то са посебним освртом на извесне аналитичке ставове појединих тадашњих критичара о овој причи.

\section{Николаћ Малебашија}

Иза овог летимичног прегледа констатација о Јелениним приповеткама родног карактера, у њен наративни корпус улазе и приче Николаћ Малебашија и Батка Бунча и Стринка Мариче, обе штампане у СКГ, прва 1903, а друга 1905. године. Њима књижевница употпуњује новим сликама и приликама целину из протеклог времена вароши, у којима су, сада, главни јунаци - мушкарци. Нарација Николаћ Малебашија (чувар реда у махали) пружа одређене особености из суживота хришћана и муслимана, односно Срба у граду још увек под Османлијама.

Књижевница гради причу око извесне несугласице између овог чувара реда и представника градских власти у вези са његовом неодоговорношћу у поштовању наредбе да се одазове саслушању. Неспоразум је брзо отклоњен Николаћевим објашњењем властима да је баш тога дана Св. Ђорђе, његова крсна слава, што захтева традиционално поштовање обичаја (после сечења славског колача, домаћин не иде од куће). Тада је Малебашија за своје поштовање и чување вере награђен „нишаном” - даровницом: свој доживљај таквог признања он својој породици објашњава скоро беседничким речима, пуним поноса: „Не ли видите? Нишан... Несам стекаја ни куће, ни дућани, ни лојза, ама сам стекаја ништо поголемо. Јербо куће, дућани ... се купују за паре ... а што сам ја стекаја, не се може да купи за паре... ете донесе ми чес'..."13

Жанр слике са почетка приповедног дискурса (природа, жене-кућанице, обележавање крсне славе) јесте позадина у коју се смешта централна идеја приче о одговорности, али пре свега, о високом поштовању своје вере. Са идеализацијом ликова, догађања и сусрета дат је и идеализован крај: добром хришћанину награда - „нишан” (даровница). Ова прича, конципирана на хришћанској идеологији, у наратолошкој форми, темељи се на новозаветној традицији светачког поштовања. Иако је такав модел дискурса у литератури, по речима Петра Милосављевића, већ „после ренесансе и барока у великој

\footnotetext{
${ }^{11}$ Бранково коло VII, св. 22, 1901, стр. 702

${ }^{12}$ Коло, књ. 1, св. 9, 1901.

${ }^{13}$ Николаћ Малебашија, СКГ, 1903, стр. 100
} 
мери маргинализован и одгурнут"14, овде се, са извесним елементима беседе (сачуван утицај из антике), добија другачији и шири наратолошки модел. Тако је списатељица преко сегмента „свечане” беседе другог наратива актера приче, овај поджанр употребила као модус савременијег литерарног обликовања личности Малебашије.

Јелена Димитријевић је приповетку Николаћ Малебашија сачинила у највећем броју од слика у низу које дају праволинијско излагање са детаљима о кући и у кући, затим о личностима, по теоретисању Мике Бала, што би представљало реалистичку нарацију. Приповедни модел овде носи и бројне драмске одлике, те жанр слике прелази у сликовити мизансцен, који је оживљен дијалозима у аутентичном нишком жаргону. А, од самог почетка је евидентно и специфично прожимање прозних и поетских жанрова где наратив конкретно наводи прве строфе, тада познатих песама, чинећи при том осврт и на начин вокалне интерпретације. Тако, поетски жанрови добијају функцију темпоралне каузалности у представљању пратећих ликова из Николаћевог окружења. Оваква жанровска трансгресија методолошки представља, према Магдалени Кох, „стваралачку технику”, која је одраз тада савременијег, модерног излагања. Оваквим композиционим поступком књижевница Димитријевић је у хронотопу времена и простора начинила причу Николаћ Малебашија, која би својом стилизацијом припала посткласичној наратологији. Међутим, фабуларно пренаглашена идеја о чувању и очувању вере, идеализација односа људи, и све то у локалном жаргону, чине ово дело анахроним према тада модерним стремљењима.

\section{Батка Бунча и Стринка Мариче}

Ова „Приповетка Г-ђе Јелене Димитријевић, кроз две свеске, Српски књижевни гласник, књ. XIV, св. 4 и св. 5, 1905."15 пружа наратолошку слику јужносрбијанске вароши, за коју је књижевница инспирацију нашла у њеном (мало)грађанском слоју друштва. Ту је она, кроз жанровски склоп нарације и кроз хронотоп места и времена, дала, у „новом” добу, одреднице духа људи који су другачији од раније познатих грађанских слојева у њеним до тада објављеним делима. Причу је ауторка формирала из три одељка, у којима су, по особинама, дата два различита соја људи: Стринка Мариче са тачном животном организацијом и Батка Бунча, у дезорганизацији живота, са својом напраситом нарави.

Тодор Стојановић, по хировитом понашању назван „Батка Бунча”, практикант из Београда, преласком у нишку варош понео је у багажу свога карактера и устаљене навике. На особености његове личности ауторка хуморно упућује од самог почетка и описивањем његовог промишљања и изгледа: „Што се тиче њега, многа би [...] за њега пошла: леп, управо био би врло 152

${ }^{14}$ Петар Милосављевић, Дискурс романа „Дневник о Чарнојевићу” Милоша Црњанског, стр.

${ }^{15}$ Из Садржаја СКГ, 1905 , св. 4, стр. 241-250 и св. 5, стр. 320-333 
леп да није много црн и да му није десно раме више - и то доста - од левога: уредан, чист [...] није Бог зна како бистар, али поштен, и врло миран, јагње: мислиш не зна да се наљути. Па готово и не би знао да му није једне болести (тако да кажемо) [...] Гадљив! гадљив!” Због те своје „болести” он се не задржава дуже ни у једном изнајмљеном стану у овој вароши. Кроз дискурс о тражењу смештаја, наратив усмерава приповедни ток на дијалошку конверзацију између станодавке Стринке Мариче и Батка Бунче, где су са погодбом обоје били задовољни, а он и више, али за кратко. Наративни заплет настаје када се (осмог дана) уместо Стринке Мариче појавила њена ћерка, Васка, млада и лепа девојка. Неприпремљен за такав сусрет, и у потпуном неспоразуму са девојком и са собом, Батка Бунча показује свој карактер. Даље, кроз наративност у сценском понашању и конверзацији, он у својој умишљености не сагледава стварност и прелази на драмски бучно понашање, изјављујући: „Ова ми је соба као гробница...” и, сипајући увреде због умишљене прљавштине и разбијајући оно што му се нашло под руком, нагло се исељава. У завршном одељку, схвативши шта је изгубио „бежећи” из куће Стринка Маричине, враћа се тамо, замишљајући и просидбу њене кћери. Причу о измењеној (породичној) ситуацији, ауторка, као наратив, претвара у наративност кроз ранију познати сценски приказ Батка Бунчине бахатости, са завршним монологом, који Стринка Мариче „сажаљиво изговара: - А, ти Боже, [...] Буди га саздаде јексик у снагу, зашто и у памет? ...”

Обликујући лик овог хистеричног незадовољника свим и свачим, Јелена Димитријевић преко трагикомичних и понегде карикатуралних ситуација, означава његово стање термином „болест”, са карактеристиком „гадљив”. По Фројдовој теорији о неурозама, из текстова Обична нервоза и Страх, у књизи Увод у психоанализу, Неурозе, хистерично понашање је назначено термином „болест”, а један од узрочника овог стања, односно, хистеричног и неуротичног понашања јесте страх (најшире узето). У Јелениној причи је страх од прљавштине, заправо од болести коју може нечистоћа да донесе. У Речнику психологије читамо дефиницију: „Хистерично: оно што се односи на различите функционалне поремећаје без органске патологије.” У побројаним компонентама које су карактеристичне за особе склоне овој врсти неурозе, између других, налазе се и инфантилност и хировитост, што и јесу, према понашању, особине Батка Бунчиног карактера. У опису стања ове личности, Јелена Димитријевић кроз приповедни дискурс, са извесним карактерним изразима, додирује Фројдову теорију о неурозама, прилагодивши стручну терминологију жаргону средине. Оваква њена књижевна формулација наводи на промишљање да је она познавала Фројдове радове, и то најпре књигу Расправе о хистерији из 1895. године. Деценију касније књижевница ствара таквог „болесног” литерарног јунака, инспирисана познатим друштвеним (не)приликама ситно-чиновничког положаја у друштву, са његовим потиснутим нерасположењем, које исказује кроз страх од „прљавштине”16.

\footnotetext{
${ }^{16}$ Антоан Поро, у тумачењу хистерије, даје, између осталог, и да хистерија „изражава неку несвесну интенционалност, а потиче из конфликата који изазивају стрепњу и незадовољство” - Енииклопедија психијатрије, стр. 209.
} 
Како су 1903. и 1905. године Павле Поповић и Јован Скерлић били сарадници у СКГ-у, а Павле Поповић 1905 . и главни уредник, нема сумње да су ове две приче Јелене Димитријевић ту штампане са њиховим уредничким „благословом”. У овом односу теоретичара и књижевнице, могућа је и претпоставка да је и сам Поповић, сходно својим теоријским начелима, иницирао да их она напише као део српског културног идентитета и обележја старог Ниша, у приповедном циклусу о овом граду.

\section{Мејрем ханум}

Свој приповедни круг о старом Нишу Јелена Димитријевић затвара причом Мејрем ханум, из збирке Фати Султан, Сафи ханум и Мејрем ханум, 1907. године. То је психолошка нарација која следи двоструко понашање Туркиње Мејрем: једно се везује за спољашњи свет, а друго за унутрашњи, само њен живот. Део приповедног тока о конверзацији између гошће из Цариграда и Мејрем хануме о спољашњем окружењу кореспондира са последњим сегментом из главе XVI, о харемима, из Писама из Ниша, а која говори о егзистенцијалном положају Турака, оних што су се иселили и оних што су остали. Међутим, поента је у изузетно сликовитој дескрипцији ноћног подсвесног молитвеног стања главне личности - Мејрем хануме - када несвесно изговара молитву пропуштену у дневном обреду. Овде, као и у причи о Николаћу, књижевница говори о духовној величини људи који поштују своју веру (хришћанску или мухамеданску).

\section{Идејност}

Јеленина прича, објављена у СКГ 1903. о суживоту хришћана и муслимана у нишкој вароши, још увек под Османлијама, са мотивом чувања вере и поштовања традиције, по приповедном времену, заузела би прво место у скупини ових приповедака. А затим, друга приповест у истом гласилу, сада из 1905. по времену дешавања радње, означила би крај целине приповедања о времену старог Ниша. Оваквим приповедним циклусом Јелена Димитријевић осветљава историјски ток јужносрбијанске вароши кроз појединачне литерарне целине из општег друштва, указујући, при томе, на значајне особине духа људи тога времена, као део националног идентитета.

По тумачењу Антона Д. Смита и Бенедикта Андерсона, које наводи Милош Ковић, национални идентитет „носи, најпре, културне појаве, и тековине, па тек онда политичке карактеристике. Ту посебну улогу имају интелектуалци који истичу важност промена у наравима и начину мишљења..." а везане су за претходни период. И даље - „Типични носиоци национализма, схваћеног као културна доктрина, јесу, дакле, људи из света уметности и науке.” Ту свакако спада књижевница Јелена Димитријевић, поред великих књижевних 
теоретичара, Павла Поповића, Богдана Поповића, Љубомира Недића, Јована Скерлића, Љубе Јовановића и бројних других из плејаде културне елите у Србији тога времена.

У методолошком поступку књижевница се определила за бинарну опозицију: старо-ново, пре-сада итд. Још једна изузетна одлика њеног стваралачког поступка у овом циклусу нишких прича јесте употреба различитих поетика према форми израза, у складу са идејношћу. По теоретисању Павла Поповића ${ }^{17}$, овде су, у уметничком представљању, присутни високи етички принципи којих се Јелена Димитријевић инспиративно држи: традиција, народно стваралаштво, поука, квалитетни узори са стране, савремена психологија.

После више од 30 година од свог хвалоспева Јелениним песмама и 20 година од последње написане приповетке из нишког миљеа, Павле Поповић у честитки за њен јубилеј (1928) потврђује свој став о правој вредности књижевног стваралаштва Јелене Димитријевић, па тиме и о корпусу приповедања из једног времена о једном делу земље.

\section{ЛИТЕРАТУРА}

Витошевић 1990: Д. Витошевић, Српски књижевни гласник 1901-1914, Београд: Институт за књижевност и уметност „Вук Караџић”, Нови Сад: Матица српска.

Димитријевић 1892: Ј. Јов. Димитријевић, Баба Краса, у мој земан и с’га, Београд: Видело.

Димитријевић 1897: Ј. Јов. Димитријевић, Писма из Ниша о харемима, Београд.

Димитријевић 1900: Ј. Јов. Димитријевић, Српска девојка, Сремски Карловци: Бранково коло.

Димитријевић 1901: Ј. Јов. Димитријевић, Ђул Марикина прикажња, Сремски Карловци: Бранково коло, књ. VII, 702.

Димитријевић 1903: Ј. Јов. Димитријевић, Николаћ Малебашија, Београд: СКГ.

Димитријевић 1905: Ј. Јов. Димитријевић, Батка Бунча и Стринка Мариче, Београд: СКГ.

Димитријевић 1907: Ј. Јов. Димитријевић, Мејрем ханум, у: збирка прича Фати Султан, Сафи ханум, Мејрем ханум, Београд: Штампарија „Доситеј Обрадовић".

Живаљевић 1901: Д. А. Живаљевић, Јелена Јов. Димитријевић. Ђул Марикина прикажња, Београд: Коло, књ. I, 583-584.

Живановић 1907: Ј. Живановић, Јелена Јов. Димитријевић: Фати султан, Сафи ханум, Мејрем ханум, Нови Сад: Летопис Матице српске, књ. 246, $116-118$

\footnotetext{
${ }^{17}$ Студија Српски комади у К. С. Народном позоришту.
} 
Живановић 1928: Ј. Живановић, Јубилеј г-ђе Јелене Јов. Димитријевић, Београд: Венац, књ. XVI, св. 4-5, 391.

Зјелињски 2004: Б. Зјелињски, Српска проза у балканском и средњоевропском контексту, у: Српска књижевност и балканске књижевности, Научни састанак слависта у Вукове дане 2002, Београд: МСЦ.

Караџић 1975: В. С. Караџић, Српска дјевојка, Српске народне пјесме, Књига прва, Београд: Просвета.

Ковић 2002: М. Ковић, Национални идентитет у „, Српском книжевном гласнику" (1901-1914), у: Зборник радова са међународног научног скупа: Национални идентитет и суверенитет у Југоисточној Европи, 8-10. децембар 1999, Београд: Историјски институт САНУ, Зборник радова, књ. 19, 403-418.

Кох 2004: М. Кох, Епистоларна проза српских списатељица прве половине 20. века, Жанровске особине, у: Прожимање жанрова у српској књижевности, Научни састанак слависта у Вукове дане 2000, Београд: МСЦ.

Милинковић 2014: Ј. Милинковић, Женска књижевност у првој серији „Српског књижевног гласника": Библиографска перспектива, у: Зборник радова Значај библиографије периодике за истраживање књижевности и културе, Београд: Институт за књижевност и уметност, 83-106.

Милосављевић 2012: П. Милосављевић, Дискурс романа „Дневник о Чарнојевићу” Милоша Црњанског, Наратолошка истраживања I, Матица српска у Дубровнику, Београд: Мирослав, Београд: Логос, Грачаница.

Митић 2005: М. Митић, Српска реалистичка приповетка у стиху с краја ХІХ века: Јелена Димитријевић - Стеван Сремац (Баба Краса и Бал у Елемиру), Београд: МСЦ.

Митић 2006: М. Митић, Јелена Димитријевић-Стеван Сремаи: Нии у причама с краја ХІХ века, у: зборник Јелена Димитријевић - живот и дело, Ниш: Центар за научна истраживања САНУ и Универзитета у Нишу, Студијска група за српски језик и књижевност Филозофског факултета у Нишу.

Пантић 2006: Јелена Димитријевић и Павле Поповић, у: Зборник реферата са научног скупа Јелена Димитријевић, живот и дело, 28. и 29. октобpa 2004, Ниш: Центар за научна истраживања САНУ и Универзитета у Нишу, Студијска група за српски језик и књижевност Филозофског факултета у Нишу, 11-20.

Пековић 2002: С. Пековић, Српски модернисти као носиоции европских утииаја, у: Српска књижевност у контексту европске књижевности Научни састанак слависта у Вукове дане 2000, Београд: МСЦ.

Поповић 1895: П. Поповић, Песме Јелене Јов. Димитријевића, у: Српски преглед, књ. І, бр. 7, Ниш, 219-220.

Поповић 1899: П. Поповић, Српски комади у К. С. Народном позоришту, Београд: Нова искра, год. I, бр. 4, 13-14.

Поповић 1929: П. Поповић, Писмо-честитка Г-ђи Јелени Димитријевић. Јубилеј г-ђе Јелене Димитријевић, Белешке, Београд: Мисао XXIX, 1,2. 
Поповић 1938: П. Поповић, Критика у српској књижевности, Прилози за КЈИФ, књ. XVIII, Београд, 657-669.

Поповић 2001-2002: П. Поповић, Сабрана дела Павла Поповића, књ. Х и XII, Београд: Завод за уџбенике и наставна средства.

Скерлић 1967: Ј. Скерлић, Историја нове српске књижевности (Данашња књижевност), Београд: Просвета, 465.

Требјешанин 2001: Ж. Требјешанин, Речник психологије, Београд: Стубови културе.

Фројд 2014: С. Фројд, Увод у психоанализу. Неурозе, Београд.

Milunka Mitić

\section{PAVLE POPOVIĆ AND JELENA DIMITRIJEVIĆ: THE CONCEPTION OF JELENA'S STORIES ABOUT NIŠ}

(Summary)

Literary cooperation between Pavle Popović and Jelena Dimitrijević that started in 1892 with her first story (in verse) from the Niš ambience, published in "Videlo", continued intensively until the publication of the first Serbian Literary Messenger (1914). In this paper, we concentrated on the early period of their cooperation, that is, until 1907, when the writer Dimitrijević published the story "Mejrem hanum", the last in the series of stories from the Niš milieu. In this narrative corpus, we placed extra emphasis on two stories: "Nikolać Malebašija" (1903) and "Batka Bunča i Strinka Mariče" (1905), both printed in the Serbian Literary Messenger, where Pavle Popović, together with Skerlić, was an associate and later also an editor. With these stories, different in gender conceptuality from her previous ones, Jelena Dimitrijević completed the literary vision of the old Niš town. With her narrative poetics and various narrative inspirations, Pavle Popović confirms his theoretical definition of a superb treatment of the characteristic features of one area as part of the national identity. 